\title{
THE EFFECT OF SHADOWING TECHNIQUE ON STUDENTS' SPEAKING ABILITY OF EIGHT GRADE AT SMP NEGERI 1 PARIGI
}

\author{
Melly Astriyani ${ }^{1} \quad$ La Miliha $^{2}$ Wa Ode Fatmawati ${ }^{3}$
}

${ }^{1}$ Halu Oleo University, Indonesia.

\begin{tabular}{l} 
ARTICLE INFO \\
\hline Keywords: \\
Speaking Ability, \\
Shadowing technique \\
How to cite: \\
DOI:
\end{tabular}

\begin{abstract}
The objective of this study is to find out the effect of shadowing technique on students' speaking ability. The design of this study is quasi experimental were consist of two classes; experimental class and control class of students' eight grade students at SMP Negeri 1 Parigi. The researcher applied purposive sampling technique. The instrument of this research was oral test in pre-test and post-test. This study was conducted from March $21^{\text {st }}$ to April 7th, 2018. The instrument used for collecting data were speaking test and the data was analyzed by using SPSS version 16.0. The findings show the students speaking score in experimental class is higher than the students speaking score in control class. It has proved by the comparison of the mean score from both control class and experimental class. The mean score of post-test in control group is 2.52 and the mean score of post-test in experimental group is 3.31. The gain score from post-test in control group to post-test in experimental group is 0.79 . Furthermore, the effect size of the study is 0.6 and it indicates there is any significant effect of shadowing technique on students' speaking ability of eight grade students' at SMP Negeri 1 Parigi. In short, shadowing technique is recommended to teacher to be use in teaching and learning process as an additional technique in teaching speaking especially to students speaking ability.
\end{abstract}

\section{INTRODUCTION}

The students sometimes find some problems to make a communication. Nurhayati (2011) said that students speaking ability are low because of several reasons. There are many students incapable of using English orally because they are 
limited opportunity to practice, lack of vocabulary, and they are difficult to understand some sentences because of pronouncing problem. And the other problem is the students frequently couldn't understand well when the other speaks and usually ask to repeat, some students understand nothing even the simple English conversation, and they usually produce some grammar errors when they try to speak and often forced into silence.

In addition, Nurhayati (2011) said that, to speak English well, students must have to feel comfortable and confident in practicing their English. By feeling comfortable and confident, students will not fear of making mistakes when speaking English. But, many students still always feel uncomfortable, unconfident, and cause of that they are still fear to making mistake when speaking English. In this case, the teacher's role is important. When teaching and learning process, the teacher must use the appropriate technique to make the students more easily in understanding the teacher's explanation. The teacher not only give the students understanding about the material but also make the students to be more motivate in learning English.

From above explanation shows that there are serious problems in students speaking English. In this case, the researcher finds this condition when doing interview with the English teacher of SMP Negeri 1 Parigi at the eighth grade students. The teacher said that the students less motivation to speaking English because they are lack of vocabulary so the students feel shy to making mistake when doing conversation and the students difficult to speaking English.

In this case, the researcher give a solution that Shadowing technique as the appropriate technique should apply in teaching speaking at SMP Negeri 1 Parigi. Shadowing technique ascribed by Professor Alexander Arguelles who has used the technique to learn many languages. Shadowing technique is a language learning technique developed by the American Professor Alexander Arguelles, first in Germany and later Korea. So, this technique can use to learn many languages.

The researcher believes that Shadowing technique is the suitable technique to students' speaking ability because Julian, 2012 ( cited in Manseur 2014) said that Shadowing technique (by using video or audio) is the best one features for students 
to practice pronunciation and train him/herself to be fluent in speaking even at home. The students can practice every time and everywhere by using video as media and using Shadowing technique. In other hand, the students can use Shadowing technique every time when they want to learn.

Torikai, 1997 (cited in Horiyama, 2012, p. 114) states that shadowing can be considered an effective approach in improving listening ability and speaking ability, which are keys component of oral communication. In other word, shadowing is an effective approach to the teacher use in English teaching and learning process to improve student's speaking ability.

In this research, the writer interested to use shadowing technique in teaching speaking at the second year students of SMP Negeri 1 Parigi. The writer choose that technique because assumes that shadowing technique is a technique can appropriate in teaching speaking class, and motivate students to well always practice English.

According to Manseur (2014, p. 18) shadowing is a method involves listening to an audio or tape and emulating it simultaneously. So, in shadowing technique, the students learn based on the media like audio or video from native speaker. The students repeat what the audio or video said at the same time. This technique will improve the student's speaking ability because they are shadow or imitate native speaker speech in directly and continuously. Shadowing technique not only helps students in speaking English but also motivates students to well learn English. The students free to choose what the audio or video their use as long as appropriate with their level capability. If the student choose advance conversation level it's can make the student difficult to shadow.

In short, shadowing technique is a simple technique to students use in every time when they want to learn. The students just need a tape or video/audio English which appropriate with their English level then they can learn in everywhere and every time without tutor. Research Question

"Is there any significant effect of shadowing technique on the student's speaking ability of Eighth Grade students at SMP Negeri 1 Parigi“? 


\section{LITERATURE REVIEW}

\section{Definition of Speaking}

Hedge, 2000 (cited in Manseur, 2014, p. 50) said that speaking ability is person's skill to express their ideas or giving information to others. It means that speaking ability is the ability to expressing thoughts and ideas in communicate or in interaction between the speaker and listener(s).

\section{The Function of Speaking}

According to Manseur (2014, p. 44 - 45) speaking has a variety of function. Those functions can be classified into three main categories:

1. Talk as Interaction

Speaking is very important to interact with other people. Richard (in Meansur 2014, p. 45) states that:

Speaking as interaction refers to what we usually mean by "conversation" and describes interaction that serves a primarily social function. When people meet, they exchange greetings, engage in small talk, recount recent experiences, and so on, because they wish to be friendly and to establish a comfortable zone of interaction with others. The focus is more on the speakers and how they wish to present themselves to each other than on the message.

Interaction is the crucial for most speaking situations since it denotes that the speaker is unavailable in talk, and the listener is interested what is said. It also means that people involved in talk wish to keep a conversation and maintain social relationships.

2. Talk as Transaction

Richards (2008) states that speaking is appertained to what is said or what are done by the speaker. Even more, the primal concern of transaction speaking is what is conveyed as a message disregarding the interaction among interlocutors. In other words, transactional focus on what is the speaker wants to say or achieve. It has to do with accomplishing some tasks, things, or objectives. In transaction talk, the 
speaker aims to get something by using some language functions, such as providing explanations, asking, confirming, describing, requesting, and other functions.

3. Talk as Performance

Richards (2008) asserts that performance talk refers to public speaking or transmits information to the audience, such as classroom presentations, public announcements, and speeches.

\section{The Aspect of Speaking}

Manseur (2014) classified components of speaking ability, such as :

\section{Grammar}

Luoma (2004, p 12) said that the students' who learn about grammar is easy to detect in their speech and writing skill.

2. Vocabulary

Vocabulary refers to the words of the speaker used to communicate their ideas. Vocabulary concerns study about how to using words.

\section{Pronunciation}

Luoma (2004, p 11) said that pronunciation is the speech sound can refer to many features of speech stream, such as individual sounds, pitch, volume, speed, pausing, stress, and intonation.

\section{Fluency}

According to Hedge (2000, p. 54) defines that fluency is the ability to speech in clear without making mistake on articulate (pronounce word by word is clear).

\section{Accuracy}

Baker and Westrup (2003, p.7) said that accurate is the speaker don't mistake in grammar, vocabulary of pronunciation.

\section{Comprehension}

Cambridge Dictionaries (in Manseur 2014, p. 55) defined that comprehension is the ability to understanding something.

\section{Concept of Shadowing Technique}

Lambert in Manseur (2014, p. 18) states that shadowing is repeating a stimulus discourse verbatim as it is being delivered. Manseur (2014, p. 18) defined that 
shadowing is speaking and listening instantly. For instance, this method involves listening to an audio or tape and emulating it simultaneously.

\section{Types of Shadowing Technique}

There are types of shadowing as follows:

1. Kurata's Types

2. Murphey's Types

3. Norman's Types

\section{Kadota and Tamai's Types}

\section{Relevant Study}

In a research, Zakeri (2014, p. 21-26) investigated the effect of shadowing technique on English Foreign Language learners' oral performance in terms of fluency at University of Tarbiz, Iran. The samples of the research conclude forty (40) learners were randomly chosen. Those samples consist of 24 females and 16 males student's Tarbiz University. To carry out the research, the forty students were divided into two groups which twenty students in each one. One group was the experimental group and the other one was the control group. The researcher gave the explanation about shadowing technique for experimental group. The researcher asked them to shadow whatever they could get including listening, speaking, and their partner's speech or anything else. Not in the control group. Both of classes were taught for one month. Both of groups were taught from the same book : Total English. The different from both of groups is the researcher using shadowing technique for the experimental group but in control group isn't. At the end of the one month, all students were given a question to talk about. Their voices were recorded, transcribed, and stored for further data analysis. The raw data was rated into SPSS software for further analysis.

To compare the two sets of scores, descriptive statistics and Independent Sample ttest were conducted. The result showed that the participants from the experimental group had a higher mean in comparison to the ones in the control group. This proves that shadowing was an effective technique in fostering the fluency of the 
participants in the experimental group. In other words, the hypothesis that shadowing improves learners' performance in terms of fluency is confirmed.

\section{RESEARCH METHODHOLOGY}

The design of this research was quasi-experimental design. The design used two classes, namely: experimental class and control class. Each class did pre-test before treatment and post-test after treatment. The researcher compared the results of pretest and post-test. The experimental class was used treatment by using shadowing technique. The control class was given by using conventional method/regular teaching method. The population of this research included the eighth grade students of SMPN 1 Parigi in the academic year 2017/2018 at second semester. The total number of students at class VIII of SMPN 1 Parigi in the academic year 2017/2018 were 61 students from 3 classes.

The marking scheme which use to measure speaking ability of the student's accuracy and fluency in speaking adopted from Penny Ur (2006). This research focuses on fluency and accuracy. For the accuracy and fluency band score can be seen in the following table:

\begin{tabular}{|c|c|c|c|c|}
\hline No & Accuracy & Score & Fluency & Score \\
\hline 1. & $\begin{array}{l}\text { Little or no language } \\
\text { produce }\end{array}$ & 1 & $\begin{array}{l}\text { Little or } \\
\text { communication }\end{array}$ & 1 \\
\hline 2. & $\begin{array}{l}\text { Poor vocabulary, mistakes } \\
\text { in basic grammar, may } \\
\text { have very strong foreign } \\
\text { accent }\end{array}$ & 2 & $\begin{array}{l}\text { Very hesitant and brief } \\
\text { utterance sometimes } \\
\text { difficult to understand }\end{array}$ & 2 \\
\hline 3. & $\begin{array}{l}\text { Adequate but not rich } \\
\text { vocabulary, makes obvious } \\
\text { grammar mistakes, slight } \\
\text { foreign accent }\end{array}$ & 3 & $\begin{array}{l}\text { Get idea across, but } \\
\text { hesitantly and briefly }\end{array}$ & 3 \\
\hline 4. & $\begin{array}{l}\text { Good range of vocabulary, } \\
\text { occasional grammar slips, } \\
\text { slight foreign accent }\end{array}$ & 4 & $\begin{array}{l}\text { Effective } \\
\text { communication in short } \\
\text { terms }\end{array}$ & 4 \\
\hline 5. & $\begin{array}{l}\text { Wide } \\
\text { appropriately } \\
\text { virtually no grammar } \\
\text { mistakes native-like or }\end{array}$ & 5 & $\begin{array}{l}\text { Easy and effective } \\
\text { communication use long } \\
\text { terms }\end{array}$ & 5 \\
\hline
\end{tabular}




\begin{tabular}{|c|c|c|c|}
\hline slight foreign accent. & & & \\
\hline Total of score : & 5 & Total of score : & 5 \\
\hline
\end{tabular}

\section{FINDINGS AND DISCUSSION}

\section{Pre-Test}

1. Experimental Class

\begin{tabular}{|c|l|c|c|c|}
\hline No & \multicolumn{1}{|c|}{$\begin{array}{c}\text { Composition } \\
\text { category }\end{array}$} & $\begin{array}{c}\text { Interval } \\
\text { score }\end{array}$ & Frequency & Percentage (\%) \\
\hline 1 & Very good & 5 & 0 & 0 \\
\hline 2 & Good & 4 & 0 & 0 \\
\hline 3 & Moderate & 3 & 0 & 0 \\
\hline 4 & Poor & 2 & 9 & $45 \%$ \\
\hline 5 & Very poor & 1 & 11 & $55 \%$ \\
\hline \multicolumn{2}{|c|}{ TOTAL } & 20 & $100 \%$ \\
\hline
\end{tabular}

The table above describes about the distribution of students' score on pre-test in experimental group. As can be seen from the table, it can be concluded that there is no students get very good (5), good (4), and moderate (3) at the pre-test. Moreover, the majority of students get very poor criteria. There are eight students categorized as poor (2), 11 students categorized as very poor criteria (1). After analyzing the data, it can be concluded that most students' score on pre-test in experimental group was distributed into 'very poor' category. So, students' speaking skill should be developed by using shadowing technique through video as the media in teaching English in the experimental group.

2. Control Class

\begin{tabular}{|c|l|c|c|c|}
\hline No & $\begin{array}{c}\text { Composition } \\
\text { category }\end{array}$ & $\begin{array}{c}\text { Interval } \\
\text { score }\end{array}$ & Frequency & Percentage (\%) \\
\hline 1 & Very good & 5 & 0 & 0 \\
\hline 2 & Good & 4 & 0 & 0 \\
\hline 3 & Moderate & 3 & 0 & 0 \\
\hline 4 & Poor & 2 & 7 & $35 \%$ \\
\hline 5 & Very poor & 1 & 13 & $65 \%$ \\
\hline \multicolumn{2}{|c|}{ TOTAL } & 20 & $100 \%$ \\
\hline
\end{tabular}

Based on the table above describes about the distribution of students' score on pretest in control group. As can be seen from the table, it can be concluded that there is no students get very good (5), good (4), and also moderate (3) at the pre-test. Moreover, the majority of students get very poor criteria. There are 7 students 
categorized as poor (2), 13 students categorized as very poor criteria (1). In other hand, it can be concluded that most students' score on pre-test in control group was distributed into 'very poor' category. The result of pre-test score of students' in experimental group and control group is balance. There is no significant difference.

\section{Post-Test}

1. Experimental Class

\begin{tabular}{|c|l|c|c|c|}
\hline No & $\begin{array}{c}\text { Composition } \\
\text { category }\end{array}$ & $\begin{array}{c}\text { Interval } \\
\text { score }\end{array}$ & Frequency & $\begin{array}{c}\text { Percentage } \\
\mathbf{( \% )}\end{array}$ \\
\hline 1 & Very good & 5 & 0 & 0 \\
\hline 2 & Good & 4 & 6 & $30 \%$ \\
\hline 3 & Moderate & 3 & 10 & $50 \%$ \\
\hline 4 & Poor & 2 & 4 & $20 \%$ \\
\hline 5 & Very poor & 1 & 0 & 0 \\
\hline \multicolumn{2}{|r|}{ TOTAL } & 20 & $100 \%$ \\
\hline
\end{tabular}

The table showed the distribution of students' post-test in experimental group. From the table above, we can see that there is no student has the highest score which classified as very good criteria (5) score. It has clear from the table that the lowest percentage of students' score on post-test in experimental group got $0 \%$ which classified as very poor criteria (1). Meanwhile, 30\% students got score (4) which classified as good criteria, 50\% students got (3) which classified as moderate and 20\% student got (2) as poor criteria. In other hand, shadowing technique is a great technique in teaching English on students speaking ability by using the video as a media in teaching and learning process.

2. Control Class

\begin{tabular}{|c|l|c|c|c|}
\hline No & \multicolumn{1}{|c|}{$\begin{array}{c}\text { Composition } \\
\text { category }\end{array}$} & $\begin{array}{c}\text { Interval } \\
\text { score }\end{array}$ & Frequency & $\begin{array}{c}\text { Percentage } \\
\mathbf{( \% )}\end{array}$ \\
\hline 1 & Very good & 5 & 0 & 0 \\
\hline 2 & Good & 4 & 1 & $5 \%$ \\
\hline 3 & Moderate & 3 & 7 & $35 \%$ \\
\hline 4 & Poor & 2 & 12 & $60 \%$ \\
\hline 5 & Very poor & 1 & 0 & 0 \\
\hline \multicolumn{2}{|c|}{ TOTAL } & 20 & $100 \%$ \\
\hline
\end{tabular}

Based on the table above, we can see the distribution of students score on post-test in control group. There is no student got very good $(0 \%)$ criteria. There is a students' 
get a good criteria. Then, seven students get moderate criteria. Meanwhile, there are 12 students get poor criteria with score 2-2,75 and there is no students' get very poor criteria. It shows that teaching English by using shadowing technique is better than conventional method. There is no significant improvement to the students' speaking ability.

\section{Hypothesis Testing}

Summary of Hypothesis Testing

\begin{tabular}{|c|c|c|c|c|}
\hline Df & t-test & Symbol & t-table & Result \\
\hline 38 & 4.001 & $>$ & 2.042 & $\begin{array}{c}\mathrm{H}_{0}: \text { Rejected } \\
\mathrm{H}_{1}: \\
\text { Accepted }\end{array}$ \\
\hline
\end{tabular}

Based on the table above, it shows that value of $t$-test is higher than $t$-table. It means that $\mathrm{H}_{0}$ is rejected and $\mathrm{H}_{1}$ is accepted. Therefore, the there is any significant effect of shadowing technique on students' speaking ability of eighth grade students' at SMP Negeri 1 Parigi.

\section{Discussion}

The findings indicate that there is a significant effect of shadowing technique on students' speaking ability after applies of eighth grade SMP Negeri 1 Parigi. The effect comes from some factors. Those factors were students' motivation, technique used, and students' interest.

The researcher begins with students' oral communication to know their base knowledge in speaking before apply shadowing technique. The researcher saws that many problems of students' speaking performance. After applied the shadowing technique in the experimental group the result shows positive effect on students' speaking ability. The researcher believed that increasing of students' speaking ability is caused by of using shadowing technique. Chaouki said that shadowing refers to the process of emulating a certain speech. The shadower listens to the auditory input over headphones and repeats what the speaker says. In this practice, the listener shadows out loud a source language as soon as it is heard using minimal pauses as possible. Chouki added that shadowing technique is an efficient strategy to improves speaking skill and appropriate for all the language levels, which means that it can be applicable by beginner, intermediate, and advanced learners. (2016, p. 
100). In short, the students' have different result before and after apply shadowing technique. They are easily in practice English conversation by using shadowing technique.

Then the researcher believed that the significant effect of students' speaking ability caused of Shadowing technique it was supported by Omar and Umehara (2010, p. 199-230) in their research entitled "Using a Shadowing Technique to Improve English Pronunciation Deficient Adult Japanese Learners". That research concluded that by shadowing technique, there was improvement on the participants' English pronunciation, especially in their English rhythms.

The result of test, teaching speaking by using shadowing technique make the students easy to speak in well. Caused students learn based on the media like a video from native speaker. The students repeat what they heard from the video at the same time. This technique was improved the students speaking ability because they are shadow or imitate native speaker speech in directly and continuously. Shadowing technique not only helps students in speaking English but also motivates students to learn English well. (Manseur, 2014).

\section{CONCLUSION AND RECOMMENDATION}

The findings and discussion show that there is a significant effect on students speaking ability before and after treatment. Data analysis showed the difference between the mean score pre-test for experimental group is 1.6000 , and the mean score of post-test is 3.3125 with the increasing value is 1.7125 point. While the mean score of pre-test in control group is 1.4625, and the mean score of post-test is 2.5250 with the increasing value is 1.0625. The score is increased of applying Shadowing technique in teaching speaking of eighth grade SMP Negeri 1 Parigi. the researcher recommended as follows:

1. The researcher suggested that students to be more active in teaching and learning process, especially in practicing their English.

2. Shadowing technique is recommended to teacher to be used in teaching and learning process as an additional technique in teaching speaking, especially to improve students speaking ability. 
3. To the next researchers are recommended to conduct a research about the use Shadowing technique on other skill besides. Because the theory believes that Shadowing technique not only works in teaching English but also works in teaching listening

\section{REFERENCES}

Arikunto, S. (2006). "Research Procedure A Practical Approach." Jakarta: Rineka Cipta.

Burns, A., \& Joyce, H. (1997). Focus on speaking. Sydney: National Center for English LanguageTeaching and Research.

Hamzah Md Omar, M. and U. Miko "Using'A shadowing'technique'to improve english pronunciation deficient adult Japanese learners: An action research on expatriate japanese adult learners." Journal of Asia TEFL 7(2): 199-230

Horiyama, A. "The development of English language skills through shadowing exercises." Journal of Bunkyo Gakuin University of Foreign Studies, Bunkyo Gakuin Junior College(12): 113-123.

Torikai, S. "General English Words in English Legal Discourse." Language, culture, and communication: journal of the College of Intercultural Communication 6: 87-103.

Ur, P. (1996). A course in language teaching, Ernst Klett Sprachen.

Zakeri, E. "The Effect of Shadowing on EFL Learnersâ€ $€^{\mathrm{TM}}$ Oral Performance in Term of Fluency." International Journal of English Language Teaching 2(1): 21-26. 